\title{
OPEM
}

www.opem.org

Oriental Pharmacy and Experimental Medicine 2008 8(3), 215-221

DOI 10.3742/OPEM.2008.8.3.215

\section{Pharmacological findings of an Indian traditional Ayurvedic herbal formulation Amritaristo}

\author{
Runa Masuma ${ }^{1}$, MSK Choudhuri ${ }^{1}$, Sultana Rajia ${ }^{1}$ and Mahiuddin Alamgir ${ }^{2,3, *}$ \\ ${ }^{1}$ Department of Pharmacy, Jahangirnagar University, Dhaka-1342, Bangladesh; ${ }^{2}$ Pharmacy Discipline, Khulna \\ University, Khulna-9208, Bangladesh; ${ }^{3}$ School of Chemistry, University of New South Wales, Sydney, NSW-2052, \\ Australia
}

Received for publication June 07, 2007; accepted April 03, 2008

\begin{abstract}
SUMMARY
In this present study Indian traditional Ayurvedic herbal formulation Amritaristo has been studied to assess the general pharmacological effect on mice. The drug showed no significant activity on the neuropharmacological test models experimented. The increased pentobarbital sleeping time was considered related with hepatic metabolism of pentobarbital. The formulation exhibited a nonsignificant reduction of gastrointestinal motility, and devoid of any acute diuretic activity. The tested drug revealed antidiarrhoeal activity on castor oil-induced model, whereas on magnesium sulphate-induced model no effect was observed.
\end{abstract}

Key words: Amritaristo; Ayurveda; CNS; Diarrhoea; Gastrointestinal motility

\section{INTRODUCTION}

The World Health Organization (WHO) estimates, however, that one third of the world's population still lacks regular access to essential drugs with figure rising to over $50 \%$ in the poorest parts of Africa and Asia. Fortunately, in many developing countries, traditional medicines offer a major and accessible source of health care. WHO has thus focused its attention in the traditional medicine or complementary and alternative medicine into the national health care systems. WHO suggests research on the traditional medicine or complementary and alternative medicine to ensure the safety, efficacy and quality of them. The national health

\footnotetext{
${ }^{*}$ Correspondence: Mahiuddin Alamgir, School of Chemistry, University of New South Wales Sydney, NSW-2052, Australia. Tel: +610413051527; E-mail: m19alamgir@yahoo.com
}

policy of Bangladesh also has the objectives to encourage systematic improvement in the practice of the indigenous system of medicine and for utilizing the additional manpower available in this sector. Particular attention should be given to scientific evaluation of indigenous and herbal drugs (Chakraborty et al., 2006).

Ayurvedic herbal medicines are the most popular form of alternative medicine being practiced in Bangladesh. Although tremendous progress has taken place in the field of modern medicine, but the practice and use of Ayurvedic medicine is being continued throughout the country even today. Amritaristo is widely used for the treatment of fever and malaria (Anonymous, 1991). The research work was performed to assess the general pharmacological effect of Amritaristo in experimental mice. 


\section{MATERIALS AND METHODS}

\section{The formulation}

The Ayurvedic herbal preparation Amritaristo contains 22 plants, the major ten constituents are listed in Table 1. Amritaristo was collected from the Shree Kundeshwari Aushadalay and was prepared according to the Bangladesh National Ayurvedic Formulary (Anonymous, 1991). The plants were authenticated by the Bangladesh National Herbarium, Dhaka, where voucher specimens were deposited and in-process and quality control for the preparation was strictly controlled and monitored by the experienced officials of Shree Kundeshwari Aushadalay.

\section{Animals}

Male and Female mice (Swiss-webstar strain, 20 $25 \mathrm{~g}$ body weight) bred in the animal house of the Department of Pharmacy, Jahangirnagar University, were used for the experiments. The animals were provided with standard laboratory food and tap water ad libitum and maintained at natural day night cycle. The animals were divided in-groups of 6 -10, with each group balanced for sex and body weight. Amritaristo was administered per oral $40 \mathrm{ml} / \mathrm{kg}$ body weight. Control animals were administered with normal tap water. All animal experiments were approved by the Ethics Committee of the Jahangirnagar University and were in compliance with the International code of practice.

\section{Hole cross test}

The experiment was performed by Takagi et al. (1971) method. Spontaneous movement of the animals through the hole from one chamber to the other was counted for two minuets in this test. The observations were made on $0,30,60$ and 120 min after oral administration of Amritaristo.

\section{Open field test}

In this experiment, the method of Gupta et al. (1971) was employed. The floor of an open field of half square meter was divided into a series of squares, each alternatively coloured black and white. The apparatus had a wall of $40 \mathrm{~cm}$, the animals were transferred carefully to the corner of the field and the number of squares travelled by the mouse was recorded for a period of two minutes. The observations were made on $0,30,60$ and 120 min after oral administration of Amritaristo.

\section{Hole board test}

This experiment was carried out by the method of Nakama et al. (1972). Each animal was placed carefully in the center of the field and the number of holes passed, head dipping, and the number of fecal boluses excreted recorded for a period of two minutes at $0,30,60$ and 120 min after oral administration of Amritaristo.

\section{Hypnotic action of pentobarbital}

Pentobarbital induced sleeping time test was carried out according to the method of Williamson et al. (1996). Amritaristo was administered per oral 30 min before the administration of pentobarbital (50 mg/ $\mathrm{kg}$ body weight, i.p.). The animals were observed for the onset and the duration of sleep, as evidenced by the observation of the loss of righting reflex.

\section{Gastrointestinal motility test with barium sulphate $\left(\mathrm{BaSO}_{4}\right)$ milk}

This experiment was carried out by the method described by Chatterjee (1993). Barium sulphate milk $(15 \%$ barium sulphate in $0.5 \%$ NaCMC suspension) was given to a group of 12 mice (both treated and control) after $15 \mathrm{~min}$ of oral administration of Amritaristo. The treated mice were divided into two groups and were sacrificed after 15 and $30 \mathrm{~min}$ after the administration of barium sulphate milk. The distance traversed by milk were measured and expressed as a percentage of the total length of small intestine (from pylorus to the ileoceccal junction). 


\section{Castor oil induced antidiarrhoeal activity test}

The method of Yegnanarayan and Shrotri, 1982 was followed. The mice were all screened initially by giving $0.50 \mathrm{ml}$ of castor oil orally and only those showing diarrhoea were selected for further study. Amritaristo pre-treatment was given orally $1 \mathrm{~h}$ before the mice were administered with the standard dose of $0.50 \mathrm{ml}$ of castor oil. The animals were caged individually and examined for the presence of diarrhoea hourly for four hours after the castor oil challenge. Diarrhoea was defined as the presence in the stool of fluidy material, which stained the absorbent paper placed beneath the cage. The number of stools passed during the four-hour period was noted for each rat.

\section{Magnesium sulphate-induced antidiarrhoeal activity test}

The Amritaristo was administered to groups of six mice, $60 \mathrm{~min}$ before the administration of the cathartic agent magnesium sulphate in a dose of $4 \mathrm{~g} / \mathrm{kg}$. Following the administration of the magnesium sulphate, the animals were placed separately in acrylic cages with filter paper, which was changed every hour. The latent period was measured and the severity of diarrhoea was assessed each hour for four hours (Zavala et al., 1998). The number of stools passed during the four-hour period was noted for each mouse.

\section{Acute diuretic study}

The effect of the Amritaristo preparation on acute diuretic study was tested by using a "Nalgene Metabolic Cage". After the administration of the test preparation the water intake, as well as urination was measured at every hour for eight hours (Khan and Choudhuri, 1998).

\section{Statistical analysis}

Statistical analysis was performed by SPSS 10.0 for Windows. Independent samples $t$-test was done as the test of significance. Values were considered significantly different if $P<0.05$. Data were expressed as mean \pm S.E.M.

\section{RESULTS AND DISCUSSION}

In this research work the general pharmacological activity of an Indian traditional Ayurvedic herbal formulation Amritaristo was studied in experimental mice. The neuropharmacological activity of Amritaristo was evaluated by different experimental mice models. The hole cross test is designed to evaluate effects on the exploratory behavior. In order to investigate the effects of the formulation on the exploratory behavior of the treated animals, this test was performed. It has been experimentally proven that, in the absence of a special task to perform, the behavior of a given

Table 1. Major compositions of the Ayurvedic formulation Amritaristo

\begin{tabular}{lcc}
\hline Plants & Parts & Quantity \\
\hline Tinospora cordifolia (Willd.) Miers & Stem & $4.8 \mathrm{~kg}$ \\
Gmelina arborea Linn & Stem bark & $480 \mathrm{~g}$ \\
Tribulus terrestris Linn. & Root & $480 \mathrm{~g}$ \\
Solanum xanthocarpum Schrad. \& Wendl & Root & $480 \mathrm{~g}$ \\
Oroxylum indicum Linn. & Root & $480 \mathrm{~g}$ \\
Clerodendrum phlomidis Linn f. & Root & $480 \mathrm{~g}$ \\
Aegle marmelos Corr. & Root & $480 \mathrm{~g}$ \\
Solanum indicum Linn. & Root & $480 \mathrm{~g}$ \\
Stereospermum suaveolens DC. & Root & $480 \mathrm{~g}$ \\
Desmodium gangeticum DC. & Root & $480 \mathrm{~g}$
\end{tabular}


Table 2. Effect of Amritaristo on central nervous system on mice ${ }^{a}$

\begin{tabular}{|c|c|c|c|c|}
\hline \multirow{2}{*}{ Group } & \multicolumn{4}{|c|}{ Observation time (min) ( $P$ value $)$} \\
\hline & 0 & 30 & 60 & 120 \\
\hline \multicolumn{5}{|c|}{ Hole cross test } \\
\hline $\mathrm{CON}$ & $1.00 \pm 0.37$ & $1.67 \pm 0.54$ & $0.67 \pm 0.49$ & $1.17 \pm 0.54$ \\
\hline AMR & $2.00 \pm 1.00$ & $0.50 \pm 0.50$ & $2.00 \pm 0.93$ & $0.33 \pm 0.21$ \\
\hline \multicolumn{5}{|c|}{ Open field test } \\
\hline $\mathrm{CON}$ & $122.83 \pm 6.5$ & $56.17 \pm 10.28$ & $47.00 \pm 11.62$ & $39.67 \pm 8.66$ \\
\hline AMR & $109.33 \pm 9.71$ & $34.67 \pm 10.06$ & $49.17 \pm 14.61$ & $34.00 \pm 8.78$ \\
\hline \multicolumn{5}{|c|}{ Hole board test (Ambulation) } \\
\hline $\mathrm{CON}$ & $16.17 \pm 3.99$ & $18.00 \pm 4.38$ & $16.50 \pm 4.46$ & $17.50 \pm 3.02$ \\
\hline AMR & $22.83 \pm 5.38$ & $16.67 \pm 4.51$ & $21.83 \pm 3.48$ & $25.00 \pm 5.93$ \\
\hline \multicolumn{5}{|c|}{ Hole board test (Head dipping) } \\
\hline $\mathrm{CON}$ & $3.00 \pm 1.53$ & $1.83 \pm 0.75$ & $4.00 \pm 2.25$ & $2.67 \pm 1.71$ \\
\hline AMR & $1.83 \pm 0.70$ & $1.50 \pm 0.76$ & $3.67 \pm 2.06$ & $2.67 \pm 1.12$ \\
\hline \multicolumn{5}{|c|}{ Hole board test (Defecation) } \\
\hline $\mathrm{CON}$ & $1.17 \pm 0.48$ & $0.67 \pm 0.49$ & $0.50 \pm 0.34$ & $1.00 \pm 0.26$ \\
\hline AMR & $1.83 \pm 0.60$ & $0.67 \pm 0.67$ & $1.17 \pm 0.40$ & $0.83 \pm 0.54$ \\
\hline
\end{tabular}

${ }^{a}$ Values are expressed as mean \pm S.E.M. $(n=6)$. CON: Control group; AMR: Amritaristo group.

animal tend to maintain that inner activation level that is, at times, inconsistent with the actual level of activation of the animals. In order to get a picture as possible, on the effect of the drug on exploration, the open field test was performed. The hole board test is somewhat related to the open field situation, but here animals are provided with a stronger stimulus for exploratory behavior, represented by the holes, which the animals explore by inserting their head into them. A pattern of behavior characterized by exploration, (head dipping through the holes), locomotion (ambulation past the holes) and emotional defaecation are evoked in the hole-board test (Hannan et al., 2003). However, none of the above experiments (Table 2) showed any significant effect on the nervous system, suggesting Amritaristo possibly had no effect on the central nervous system.

Many a central depressant elicit their effect by interfering with the functions of the cerebral cortex. A most important method of investigating the probable cortical manifestation of a drug is to check its effect on the pentobarbital narcosis as pentobarbital has multifarious effects on the cerebral cortex (Bowman and Rand, 1980). The pentobarbital sleeping time test was performed to find out whether the water extract of the plants have any effect on the cerebral cortex. As like many other centrally active drugs, barbiturates work on the cerebral cortex and thus produce their actions. Pentobarbital, a barbiturate class hypnotic drug by an allosteric modification of $\mathrm{GABA}_{\mathrm{A}}$ receptor increases the chloride conductance and potentiates $\mathrm{GABA}_{\mathrm{A}}$ mediated postsynaptic inhibition (Katzung, 2001). Amritaristo significantly decreased the sleeping latency and increased the duration of sleep (Table 3), which is classically related to central nervous system depressant drugs. As Amritaristo had no effect on the previous neuropharmacological models, so the increased pentobarbital activity was considered related with the hepatic metabolism of pentobarbital (Williamson et al., 1996).

From the barium sulphate induced gastrointestinal motility test (Table 4) we observed that the Amritaristo have a tendency to reduce the gastrointestinal motility. In the castor oil-induced diarrhoeal 
Table 3. Effect of Amritaristo on the hypnotic action of pentobarbital ${ }^{\mathrm{a}}$

\begin{tabular}{ccc}
\hline Group & Onset of sleep & Duration of sleep \\
\hline Control & $6.30 \pm 0.52$ & $41.70 \pm 5.25$ \\
Amritaristo & $3.14 \pm 0.40^{* * *}$ & $109.57 \pm 15.88^{* * *}$ \\
\hline
\end{tabular}

${ }^{\mathrm{a}}$ Values are expressed as mean \pm S.E.M. $(\mathrm{n}=10)$ in min. ${ }^{* *} P<0.01,{ }^{* * *} P<0.001$.

experiment Amritaristo non-significantly increased the latent period, however it significantly decreased the number of stool count at one and four hours. The formulation did not show any significant effect on the magnesium sulphate-induced diarrhoeal test (Table 5). The castor oil model incorporates both secretory and motility diarrhoea (Yegnanarayan and Shrotri, 1982). The liberation of ricinoleic acid from castor oil results in irritation and inflammation of the intestinal mucosa, leading to the release of prostaglandins, which stimulates motility and secretion (Pierce et al., 1971). Ricinoleic acid was also reported to reduce active $\mathrm{Na}^{+}$and $\mathrm{K}^{+}$absorption with decreased $\mathrm{Na}^{+}, \mathrm{K}^{+}$ATPase activity in the small intestine and colon (Gaginella and Phillips, 1975). Whereas, magnesium sulphate produces diarrhoea by the osmotic properties, preventing reabsorption of water ions, leading to increment of the volume of the intestinal content. This salt also promotes the liberation of cholecystokinin from the duodenal mucose, which increases the secretions and has a motor effect on the small intestine and also prevent reabsorption of sodium chloride and water (Zavala et al., 1998). Having effect on the castor oil model suggests antisecretory mechanism to be involved in the antidiarrhoeal activity. Which was also marked from the lower number of fluidy stools counted during the experiment. Amritaristo had no effect on the acute diuretic study in our model (Table 6).

Ayurvedic medical treatment involves with complex combinations of several herbs. In some cases, the medicinal value of the preparation may be due entirely to the combination of constituents and cannot be reproduced by one or two so called

Table 6. Diuretic study of Amritaristo

\begin{tabular}{lcc}
\hline \multirow{2}{*}{ Group } & \multicolumn{2}{c}{$0-8 \mathrm{~h}$} \\
\cline { 2 - 3 } & $\begin{array}{c}\text { Water intake } \\
(\mathrm{ml})\end{array}$ & $\begin{array}{c}\text { Urination } \\
(\mathrm{ml})\end{array}$ \\
\hline Control $(\mathrm{n}=6)$ & 7.00 & 3.75 \\
Amritaristo $(\mathrm{n}=6)$ & 7.50 & 3.00 \\
\hline
\end{tabular}

Table 4. Effect of Amritaristo on $\mathrm{BaSO}_{4}$ induced gastrointestinal motility ${ }^{\mathrm{a}}$

\begin{tabular}{lcccccc}
\hline \multirow{3}{*}{ Group } & \multicolumn{3}{c}{15 min study } & \multicolumn{3}{c}{30 min study } \\
\cline { 2 - 6 } & Total length & $\begin{array}{c}\text { Length } \\
\text { traversed }\end{array}$ & \% traversed & Total length & $\begin{array}{c}\text { Length } \\
\text { traversed }\end{array}$ & \% traversed \\
\hline Control & $54.25 \pm 1.51$ & $38.68 \pm 3.99$ & $71.32 \pm 7.1$ & $50.57 \pm 1.65$ & $36.62 \pm 1.71$ & $72.99 \pm 4.72$ \\
Amritaristo & $50.43 \pm 2.28$ & $31.03 \pm 5.22$ & $60.75 \pm 8.2$ & $55.33 \pm 1.25$ & $29.33 \pm 5.05$ & $53.02 \pm 9.14$ \\
\hline
\end{tabular}

${ }^{a}$ Values are expressed as Mean \pm S.E.M. $(n=6)$.

Table 5. Effect of Amritaristo on the diarrhoeal model experiment $\mathrm{a}^{\mathrm{a}}$

\begin{tabular}{|c|c|c|c|c|c|}
\hline \multirow{2}{*}{ Group } & \multirow{2}{*}{ Latent Period } & \multicolumn{4}{|c|}{ Number of stool } \\
\hline & & $1 \mathrm{~h}$ & $2 \mathrm{~h}$ & $3 \mathrm{~h}$ & $4 \mathrm{~h}$ \\
\hline \multicolumn{6}{|c|}{ Castor oil induced antidiarrhoeal activity test } \\
\hline Control & $16.17 \pm 8.21$ & $7.33 \pm 1.65$ & $3.67 \pm 1.06$ & $1.83 \pm 0.79$ & $2.50 \pm 0.96$ \\
\hline Amritaristo & $30.80 \pm 14.49$ & $1.20 \pm 0.37^{* *}$ & $2.20 \pm 1.46$ & $1.60 \pm 0.81$ & $0.20 \pm 0.20$ \\
\hline \multicolumn{6}{|c|}{ Magnesium sulphate-induced antidiarrhoeal activity test } \\
\hline Control & $15.67 \pm 7.49$ & $3.00 \pm 0.82$ & $3.00 \pm 0.58$ & $2.67 \pm 0.71$ & $1.50 \pm 0.62$ \\
\hline Amritaristo & $39.40 \pm 34.93$ & $6.00 \pm 1.87$ & $2.25 \pm 1.12$ & $1.40 \pm 0.87$ & $2.40 \pm 0.75$ \\
\hline
\end{tabular}

${ }^{\mathrm{a}}$ Values are expressed as mean \pm S.E.M. $(\mathrm{n}=6)$, latent period are in $\min .{ }^{*} P<0.05,{ }^{* *} P<0.01$. 
active principles alone. This medical benefit because of the mix of constituents that have synergistic effects and act upon different molecular targets (Williamson, 2001; Wagner, 2004). The chemical constituents reported from the dominating plant of the formulation Tinospora cordifolia, belong to different classes such as alkaloids, diterpenoid lactones, glycosides, steroids, sesquiterpenoid, phenolics, and polysaccharides. The notable medicinal properties reported are anti-diabetic, anti-periodic, anti-spasmodic, anti-inflammatory, anti-arthritic, anti-oxidant, anti-allergic, anti-stress, anti-leprotic, anti-malarial, hepatoprotective, immunomodulatory and anti-neoplastic activities (Singh et al., 2003). Among the other major plants Gmelina arborea (Abdulkarim et al., 2005), Clerodendrum phlomidis (Rani et al., 1999) and Aegle marmelos (Mazumder et al., 2006) have been previously reported to have antidiarrhoeal activity, and might be responsible for the current antidiarrhoeal activity. Further studies with this formulation and individual ingredients are suggested to have a clear picture of the activity.

\section{REFERENCES}

Abdulkarim A, Sadiq Y, Onyiloyi A, Umar Z, Mukhtar A. (2005) Evaluation of five medicinal plants used in diarrhoea treatment in Nigeria. J. Ethnopharmacol. 101, 27-30.

Anonymous. (1991) Bangladesh National Formulary of Ayurvedic Medicine, National Unani and Ayurvedic Formulary Committee Bangladesh. Bangabandhu Avenue, Dhaka: Board of Unani and Ayurvedic System of Medicine.

Bowman WC, Rand MJ. (1980) Textbook of Pharmacology. 2nd ed., Blackwell Scientific Publications, New York.

Chakraborty S, Rajia S, Choudhuri MSK, Hossain MF, Sattar M, Shrestha T. (2006) Some pharmacological findings of non therapeutic importance of an Ayurvedic preparation Chandanasav. Orient. Pharm. Exp. Med. 6, 157-160.

Chatterjee TK. (1993) Handbook on Laboratory Mice and Rats, 1st ed., p.157, Department of Pharmaceutical Technology, Jadavpur University, India.

Gaginella TS, Phillips SF. (1975) Ricinoleic acid: current view of an ancient oil. Am. J. Dig. Dis. 20, 1171-1177. Gupta BD, Dandiya PC, Gupta ML. (1971) A psycho pharmacological analysis of behavior in rat. Jpn. J. Pharmacol. 21, 293-298.

Hannan J, Shahriar M, Islam M, Sattar M, Haque S, Choudhuri M. (2003) Neuropharmacological study of some Ayurvedic medicinal plants. Orient. Pharm. Exp. Med. 3, 8-17.

Katzung BG. (2001) Basic and Clinical Pharmacology. 8th ed., McGraw-Hill, New York.

Khan M, Choudhuri M. (1998) Acute and chronic metabolic study of Nigella sativa Linn. Hamdard Med. 41, 44-51.

Mazumder R, Bhattacharya S, Mazumder A, Pattnaik AK, Tiwary PM, Chaudhary S. (2006) Antidiarrhoeal evaluation of Aegle marmelos (Correa) Linn. root extract. Phytother. Res. 20, 82-84.

Nakama M, Ochiai T, Kowa Y. (1972) Effects of psychotropic drugs on emotional behavior on naïve rats in holded open field. Jpn. J. Pharmacol. 22, 767.

Pierce N, Carpenter C, Elliot H, Greenough W. (1971) Effects of prostaglandins, theophylline and cholera exotoxin upon transmucosal water and electrolyte movement in canine jejunum. Gastroenterology 60, 22-32.

Rani S, Ahamed N, Rajaram S, Saluja R, Thenmozhi S, Murugesan T. (1999) Anti-diarrhoeal evaluation of Clerodendrum phlomidis Linn. leaf extract in rats. J. Ethnopharmacol. 68, 315-319.

Singh SS, Pandey SC, Srivastava S, Gupta VS, Patro B, Ghosh AC. (2003) Chemistry and medicinal properties of Tinospora cordifolia (Guduchi). Indian J. Pharmacol. 35, 83-91.

Takagi K, Watanabe M, Saito H. (1971) Studies on the spontaneous movement of animals by the hole cross test: effect of 2-dimethylaminoethan. Its acylesters on the central nervous system. Jpn. J. Pharmacol. 21, 797-810.

Wagner H. (2004) Natural products chemistry and phytomedicine in the twenty-first century: new developments and challenges. Second International Conference on Biodiversity; New Delhi; 2004. p. 26-31. Williamson E. (2001) Synergy and other interactions in phytomedicines. Phytomedicine 8, 401-409. 
Williamson EM, Okpako DT, Evans FJ. (1996) Pharmacological Methods in Phytotherapy Research. Selection Preparation and Pharmacological Evaluation of Plant Material. England: John Willey \& Sons Ltd. Yegnanarayan R, Shrotri DS. (1982) Comparison of antidiarrhoeal activity of some drugs in experimental diarrhoea. Indian J. Pharmacol. 14, 293-299.

Zavala MA, Perez S, Perez C, Vargas R, Perez RM. (1998) Antidiarrhoeal activity of Waltheria americana, Commelina coelestis and Alternanthera repens. J. Ethnopharmacol. 61, 41-47. 